\title{
Religion, civility and the 'British' of Ireland in the 1641 Irish rebellion
}

\author{
JOAN REDMOND* \\ King's College London
}

\begin{abstract}
A B S T R A T. This article examines the 1641 Irish rebellion through a neglected manuscript account from 1643, written by Henry Jones and three of his 1641 deposition colleagues. The 'Treatise' offers important insights into the rebellion, but also advances a broader understanding of the significance of the early modern efforts to civilise Ireland and the impact of these schemes, especially plantation, on the kind of conflict that erupted in the 1640s. It is an evaluation that brings together both the long pre-history of the rebellion, and what eventually unfolded, offering new perspectives into a crucial and contested debate within modern historiography. The 'Treatise' also presents the opportunity to interrogate the position of the settler community, and their careful construction and presentation of a religiously-and culturally-driven improvement of the country. While it was a period of crisis, the rebellion offered an important opportunity to reflect on the wider project of Irish conversion and civility. It was a moment of creation and self-creation, as the emerging 'British' community not only digested the shock of the rebellion, but sought to fashion narratives that underlined their moral claims to Ireland on the grounds of true religion and civility.
\end{abstract}

$\mathrm{O}$ $\mathrm{n}$ the night of 22-3 October, the 1641 Irish rebellion broke out. It has long inspired competing interpretations, often along confessional and political lines. ${ }^{1}$ The rising's image as one of 'popish' rebellion emerged almost immediately after it began, with the men charged to investigate what happened, and especially the deposition commission's leader, Dr Henry Jones, among its earliest and most prominent advocates. Jones and his commission colleagues were crucial narrators and interpreters of the rebellion due to the immediacy of their work. ${ }^{2}$ They

* Department of History, King's College London, joan.redmond@kcl.ac.uk

${ }^{1}$ Even the name of the events of 1641-2 has never been stable, with 'rising' and 'rebellion' both used. For perspectives on the confessional and national divisions in the historiography, see Patrick J. Corish, 'The rising of 1641 and the Catholic Confederacy, 1641-5' in T. W. Moody, F. X. Martin and F. J. Byrne (eds), A new history of Ireland, iii: Early modern Ireland 1534-1691 (Oxford, 2009), pp 289-316; Walter Love, 'Civil war in Ireland: appearances in three centuries of historical writing' in Emory University Quarterly, xxii, no. 1 (spring 1966), pp 57-72; John Gibney, The shadow of a year: the 1641 rebellion in Irish history and memory (Madison, WI, 2013); for discussion of the 'general massacre' debate, see Aidan Clarke, "The "1641 massacres" in Jane Ohlmeyer and Micheál Ó Siochrú (eds), Ireland, 1641: contexts and reactions (Manchester, 2013), pp 37-51.

2 Aidan Clarke, 'The 1641 depositions' in Peter Fox (ed.), Treasures of the library: Trinity College Dublin (Dublin, 1986), pp 111-22. 
composed several treatises: A remonstrance of divers remarkable passages concerning the church and kingdome of Ireland, an appeal addressed to the English House of Commons and subsequently printed in March 1642, is among the bestknown accounts of the rebellion. ${ }^{3}$ They produced another, much less-well-known work in 1643, which provided an even fuller account of the rebellion from their perspective - 'A Treatise giving a representation of the grand Rebellion in Ireland' but it was never printed. ${ }^{4}$ This article is a closer investigation of this under-used 'Treatise', arguing for its significance as a source both for understanding the rebellion itself, and as an important reflection of the wider 'British' project of conversion and civility in seventeenth-century Ireland at a moment of crisis.

Previous work on the 'Treatise' has recognised this conjunction of religion and civility. Aidan Clarke, whose work stands almost alone in examining it closely, argued that the 1643 account aimed to warn against Irish 'cunning' and 'cruelty', but also to 'extol the Protestant dead' for future generations, informed by both antipopish tropes and the lived experience of Ireland's complex religious and colonial landscapes. This article takes up Clarke's claim that the Irish 'subsumed the rooting out of Protestantism in the eradication of civility', suggesting the primacy of 'colonial' concerns and rejection of English rule, with religion acting as a concealing cloak. ${ }^{5}$ Instead, the article argues that religion and civility marched inseparably, with the settlers' claim to a moral possession of Ireland by dint of both true religion and their improving outlook. Their wholesale rejection by the Irish represented an 'unholy war' against a totalising 'Protestant civility'. As Clarke himself acknowledged, contemporaries recognised the intimate links between religion and civility, ${ }^{6}$ and to create a hierarchy of justification is to oversimplify the dynamics of Ireland's competing communities.

While the 1643 'Treatise' will be the focus here, it is not my intention to provide a detailed account of the more technical aspects of the manuscript. I have provided a more intensive treatment of the volume, including extensive discussion of authorship, potential circulation, print and manuscript culture, and the relationship of the 'Treatise' with other texts elsewhere, and will include only a brief summary of the major aspects here.

The volume is divided into the seventy-two-side discursive tract, written in Jones's hand, and the 208 depositions appended afterwards, with Thomas Waring having written this section. Content-wise, the 'Treatise' is not a strictly

${ }^{3}$ Henry Jones, A remonstrance of divers remarkeable passages concerning the church and kingdome of Ireland (London, 1642); see also Henry Jones, A relation of the beginnings and proceedings of the rebellion in the county of Cavan (London, 1642) and Thomas Waring, A brief narration of the plotting, beginning \& carrying out of that execrable rebellion and butcherie in Ireland (London, 1650) for other works by commission members and associates.

${ }^{4}$ Henry Jones, Randall Adams, Henry Brereton and Edward Pigott, 'A Treatise giving a representation of the grand Rebellion in Ireland', 1643 (B.L., Harley MS 5999), hereafter referred to as 'Treatise'; see also A catalogue of the Harleian manuscripts in the British Museum (4 vols, London, 1808-12), iii, 309.

5 Aidan Clarke, 'The 1641 rebellion and anti-popery in Ireland' in Brian MacCuarta (ed.), Ulster 1641: aspects of the rising (Belfast, 1993), pp 156-7.

${ }^{6}$ Ibid., pp 142-5.

7 Joan Redmond, '(Re)making Ireland British: conversion and civility in a neglected 1643 treatise' in Simone Maghenzani and Stefano Villani (eds), British Protestant missions and the conversion of Europe (New York, 2020), pp 57-78. 
chronological account of the rebellion, and instead can be divided up into a number of thematic areas: the first sought to explain the motives of Irish Catholics for rebelling, and especially the 'coming together' of Gaelic Irish and Old English in a common outlook defined by their shared confession. A second theme was a concerted effort to historicise and compare the Irish rebellion with other instances of conflict; the third and final major theme concerned civility, with the rebellion characterised as a fundamental rejection of the 'happy fruits' of improvement in agricultural and economic systems, in just rule, in customs and behaviour, and especially in religion. In sum, the 'Treatise' depicted a complete rejection of the English — or 'British' project in Ireland, through focusing on the totality of the conflict and what was at stake for the wider Protestant and British community. ${ }^{8}$ As such, its chief strengths are not in reconstructing a narrative of What really happened in the strictest sense, but in tracing the commissioners' developing understanding of the causes of the rebellion, why violence took the forms it did, and broader issues concerning the 'British' project in Ireland.

As far as is possible to tell, the volume in the Harley collection is the only extant copy, and little information is available as to how it came to be in that collection. While Clarke has argued that the volume - both the 'Treatise' and the appended depositions - was intended for a 'local' readership, rather than circulation in England, ${ }^{9}$ it is my belief that the manuscript was intended for print, in a similar fashion to the Remonstrance and $A$ relation of the beginnings and proceedings of the rebellion in the county of Cavan (London, 1642), also written by Jones. Indeed, in his Relation, Jones mentioned his ongoing work on a 'generall Treatise, that shall hereafter (God willing) be set forth, of the whole progresse of that War throughout the whole Kingdom' - likely meaning this treatise, and also suggesting an intention to print. ${ }^{10}$ As such, the 1643 tract constituted not only a 'sequel' to the Remonstrance, ${ }^{11}$ but was probably intended as the third in a trilogy, along with the description of events in Cavan.

The particular tensions wracking Protestant Ireland in 1643, especially the cessation of arms negotiated with the Irish, probably explains why the 'Treatise' did not appear in print. Whether its strong line made it too controversial, ${ }^{12}$ or whether it simply missed its moment - seemingly completed in November (the cessation was agreed in September $)^{13}$ — it did not form the concluding part in Jones's print trilogy and has been overlooked as a result. Its impact as a manuscript account is difficult to trace, though we should remember that publication did not have to mean print, ${ }^{14}$ and certainly a number of highly influential works on the rebellion were printed afterwards, including Sir John Temple's The Irish rebellion,

8 Ibid.

${ }^{9}$ Clarke, 'The 1641 rebellion and anti-popery in Ireland', p. 156.

10 Jones, Relation, p. 1; Redmond, '(Re)making Ireland British', pp 63, 68-9.

11 Clarke, "1641 massacres", p. 40; idem, "The 1641 rebellion and anti-popery in Ireland', p. 151.

12 Clarke, "1641 massacres", p. 41; idem, "The 1641 rebellion and anti-popery in Ireland', p. 151; Redmond, '(Re)making Ireland British', pp 70-2.

13 Jones et al., 'Treatise', flyleaf; see also A catalogue of the Harleian manuscripts, iii, 309.

14 See for example Harold Love, Scribal publication in seventeenth-century England (Oxford, 1993), pp 39, 70-2, 174; idem, 'Oral and scribal texts in early modern England' in John Barnard and D. F. McKenzie (eds), The Cambridge history of the book in Britain, iv: 1557-1695 (Cambridge, 2002), p. 109; Noah Millstone, Manuscript circulation and the invention of politics in early Stuart England (Cambridge, 2016), pp 1-4, 17-21; 
Thomas Waring's own work, A brief narration, and the 1652 Abstract. ${ }^{15}$ Future investigation may point to the influence of the 1643 tract on these and other works, and is an exciting possibility for further research. Dianne Hall and Elizabeth Malcolm have highlighted the influence of John Foxe and Philip Vincent among others on English depictions of the rising, showing the extensive circulation and intertextual borrowing of rhetoric and imagery surrounding violence, and its cross-confessional and multinational character. ${ }^{16}$ It is highly likely both that the 'Treatise' absorbed much already disseminated about the rebellion, and that it in turn shaped the understanding of later writers.

The aim of this article is to delve deeper into a number of the most interesting themes in the 'Treatise'. More could undoubtedly be said and there is much that remains to be explored in this account. Three major areas for discussion will follow here. The first interrogates the document's account of the causes and course of the rebellion, especially the coalescing of religious and ethnic animosities. The second section investigates the extensive use of Christian ideas, imagery and rhetoric, especially neighbourliness and 'good neighbourhood', to underline the religious interpretation of the rebellion. The third part addresses the intersection of civility and improvement with these religious themes, creating the impression of the rebellion as a total war, an 'unholy' war, against 'British' Protestantism in all its facets.

Being focused heavily on the 'horridnes' of the rebellion, the 1643 'Treatise' has much to say about its origins, serving as a keyhole into Protestant understandings of events on their terms. ${ }^{17}$ Assessment of the 'Treatise' provides an opportunity to intervene in the wider historiography of 1641, which has advanced in recent years by addressing, among other themes, performative, ethnic, religious and sexual violence in $1641-2,{ }^{18}$ drawing especially on the 1641

Alexandra Walsham and Julia Crick (eds), The uses of script and print, 1300-1700 (Cambridge, 2003).

${ }^{15}$ Sir John Temple, The Irish rebellion (London, 1646); Waring, A brief narration; Anonymous, An abstract of some few of those barbarous, cruell massacres and murthers of the Protestants and English in some parts of Ireland (London, 1652). Clarke identifies Temple as a fellow opponent of the cessation alongside Jones, suggesting there may be close affinities in their outlook and works that remain to be fully investigated: Clarke, 'The 1641 rebellion and anti-popery in Ireland', p. 151. There is certainly more work to be done on Waring's writings, and how they relate to and possibly draw on the works of the deposition commissioners, given their close working relationship.

${ }^{16}$ Dianne Hall and Elizabeth Malcolm, "'The rebels Turkish tyranny": understanding sexual violence in Ireland during the 1640s' in Gender and History, xxii, no. 3 (Apr. 2010), pp 58-9, 67-8.

17 'Treatise', f. $32 \mathrm{v}$.

${ }^{18}$ MacCuarta (ed.), Ulster, 1641, esp. chapters by Gillespie, Clarke and Simms; David Edwards, Pádraig Lenihan and Clodagh Tait (eds), Age of atrocity: violence and political conflict in early modern Ireland (Dublin, 2007), esp. chapters by MacCuarta and Nicholls; Eamon Darcy, Annaleigh Margey and Elaine Murphy (eds), The 1641 depositions and the Irish rebellion (London, 2012), esp. chapters by Jones, Darcy, MacLeod and Finnegan; Ohlmeyer and Ó Siochrú (eds), Ireland: 1641, chapters by Clarke and Walter; Hall \& Malcolm, 'Understanding sexual violence', pp 55-74; Morgan T. P. Robinson, 'An act "soe fowle and grievous": contextualizing rape in the 1641 rebellion' in I.H.S., 
depositions, ${ }^{19}$ and thereby expanding our understanding of 'what really happened'. 20

As Clarke and Nicholas Canny have argued, the rebellion must be situated in its long-term as well as its short-term origins, especially the impact of efforts both to convert and to civilise the Irish — to 'make them British'. ${ }^{21}$ Both recognise the importance of religion when considering English colonial endeavours, but neither offers a full and sustained interrogation of the interdependence of religion, civility and plantation. ${ }^{22}$ As such, the question of why religion immediately emerged as a key justification on the part of the Irish, as well as a source for criticism of the rebellion and the rebels' actions, becomes more pressing. In particular, the argument that religious causes were 'subsumed' into others, providing only a veneer while other forces were in fact the chief drivers of conflict, ${ }^{23}$ demands more careful scrutiny: it was a 'Protestant civility' that arrived in Ireland from the early seventeenth century. This meant that a multiplicity of targets existed, along with a host of different possible outcomes, but religion provided the vocabulary, the legitimacy and the unifying ideology for both victims and aggressors. 'Protestantising' the conflict allowed for a war of total annihilation: a 'Romish holy warre' that rejected Protestant beliefs and the tangible evidence of a Protestant, or 'British', way of life. ${ }^{24}$ This integrated vision, presenting both cause and consequence, and the undergirding of colonial ventures with Protestantism, is central in understanding both the origins and eventual unfolding of the rebellion.

One of the key claims of the 'Treatise' concerned the establishing of a 'Protestant civility'. Civility is a thorny term of several meanings. It connoted a process, civilising, but also an end point, civilisation, and included political, social and religious signifiers. Its opposite was barbarism, which could mean a lack of civil organisation, but also the absence of other crucial elements of civility, such as clear laws, letters and a settled way of life, often based on cultivation, urban centres and trade. ${ }^{25}$ Civility could be a process: since many early modern people thought of

xxxix, no. 156 (Nov. 2015), pp 595-619; Naomi McAreavey, 'Re(-)membering women: Protestant women's victim testimonies during the Irish rising of 1641' in Journal of the Northern Renaissance, ii (2010) (http://www.northernrenaissance.org) (11 Dec. 2020); for key monograph treatments, see Eamon Darcy, The 1641 Irish rebellion and the wars of the three kingdoms (Woodbridge, 2013); Nicholas Canny, Making Ireland British, 1580 1650 (Oxford, 2001), pp 461-550 (see also his Nicholas Canny, 'What really happened in Ireland in 1641?' in Jane Ohlmeyer (ed.), Ireland from independence to occupation (Cambridge, 1995), pp 24-43); Michael Perceval-Maxwell, The outbreak of the Irish rebellion of 1641 (Montreal, 1993); Robert Armstrong, Protestant war: the 'British' of Ireland and the wars of the three kingdoms (Manchester, 2005), pp 14-68; William J. Smyth, Map making, landscapes and memory: a geography of colonial and early modern Ireland (Cork, 2006), pp 103-65.

19 The 1641 depositions project (www.tcd.ie/1641) (13 Dec. 2020). The centrality of the depositions has been firmly established, despite the challenges they pose: Nicholas Canny, 'What really happened in Ireland in 1641?', p. 27.

${ }^{20}$ Canny, 'What really happened in Ireland in 1641?', pp 26-7.

${ }^{21}$ Clarke, 'The 1641 rebellion and anti-popery in Ireland', pp 139-52; Canny, Making Ireland British, passim.

${ }^{22}$ Canny, Making Ireland British, pp 144, 202-03, 490; Clarke, 'The 1641 rebellion and anti-popery in Ireland', pp 142-9.

${ }^{23}$ Clarke, 'The 1641 rebellion and anti-popery in Ireland', pp 156-7.

24 'Treatise', f. $11 \mathrm{v}$.

${ }^{25}$ Keith Thomas, In pursuit of civility: manners and civilization in early modern England (New Haven, CT, 2018), pp xii-xvi, 1-13; Ian Campbell, Renaissance ethnicity and humanism 
civility and civilisation as either a spectrum, or a hierarchy, then change and evolution was possible, with the 'savage' and 'barbarous' becoming gradually less so through profound transformations of their political, moral and cultural organisation. ${ }^{26}$ Such understandings were critical for early modern Ireland, since this conceptualisation was at the core of desires to reform Ireland. The means to do so varied widely, from total conquest and even eradication of the native Irish, through to more 'gentle' measures of persuasion. ${ }^{27}$ However, the crucial underpinning of much of this thinking was scriptural: Paul Stevens has argued that English understandings of civility were 'inflected, underwritten and insured' by religion, and particularly scripture, with profound consequences for Ireland. ${ }^{28}$ Given the importance of the confessional divide in Ireland, how it affected thinking about civility still remains somewhat underexplored.

Teresa M. Bejan's work has highlighted the idea of 'competing' ideas of civility: this is a concept that can be applied to thinking more broadly about the different visions for early modern Ireland espoused by a range of actors, both Protestant and Catholic. ${ }^{29}$ Jane Ohlmeyer has similarly argued for 'multiple colonizations' in Ireland, acknowledging that participants, again on both sides of the confessional divide, engaged in settlement and other civilising schemes, but could selectively adopt, and adapt, many elements of such projects. ${ }^{30}$ These insights highlight that, far being from a static or standardised concept, civility was a flexible and useful category that could be deployed by several Irish constituencies, as could its antonym, barbarism. Competing civilities meant that it was possible to have, for example, Catholic landowners committed to many key ideas of improvement, but perhaps not every aspect, such as Protestantism. ${ }^{31}$ But it also meant that claims to civility — and barbarism - could be used as polemical weapons at other times. The rebellion was one such moment.

To competing civilities it is possible to marry the 'competing communities' of Robert Armstrong and Tadhg Ó hAnnracháin: ${ }^{32}$ at its heart, the rebellion was a

before race: the Irish and the English in the seventeenth century (Manchester, 2013), pp 11-14; D. K. Shuger, 'Irishmen, aristocrats, and other white barbarians' in Renaissance Quarterly, 1, no. 2 (summer 1997), pp 494-525; Clare Carroll, 'Barbarous slaves and civil cannibals: translating civility in early modern Ireland' in Clare Carroll and Patricia King (eds), Ireland and postcolonial theory (Cork, 2002), pp 63-80; Nicholas Canny, 'The ideology of English colonization: from Ireland to America' in William and Mary Quarterly, xxx, no. 4 (Oct. 1973), pp 575-98; John Patrick Montaño, The roots of English colonialism in Ireland (Cambridge, 2011), esp. pp 22-63; Paul Slack, The invention of improvement: information and material progress in early modern England (Oxford, 2015), pp 34-42; Clarke, 'The 1641 rebellion and anti-popery in Ireland', pp 142-52.

26 Thomas, In pursuit of civility, pp 183-92, 206-19; Teresa M. Bejan, Mere civility: disagreement and the limits of toleration (Cambridge, MA, 2017), pp 9-10, 16-18.

27 Canny, Making Ireland British, pp 247, 250.

${ }^{28}$ Paul Stevens, 'Spenser and Milton on Ireland: civility, exclusion and the politics of wisdom' in ariel: A Review of International English Literature, xxvi, no. 4 (Oct. 1995), p. 153; see also Clarke, 'The 1641 rebellion and anti-popery in Ireland', pp 142-3.

29 Bejan, Mere civility, p. 7; Toby Barnard, Improving Ireland? Projectors, prophets and profiteers, 1641-1786 (Dublin, 2008), p. 17.

${ }_{30}$ Jane Ohlmeyer, Making Ireland English: the Irish aristocracy in the seventeenth century (London, 2012), p. 11.

${ }_{31}$ Barnard, Improving Ireland?, pp 26-7; Ohlmeyer, Making Ireland English, p. 133.

${ }^{32}$ Robert Armstrong and Tadhg Ó hAnnracháin, 'Introduction: making and remaking community in early modern Ireland' in idem (eds), Community in early modern Ireland (Dublin, 2006), pp 19-20. 
struggle over the kind of community Ireland should be. It is in this light that the 'Treatise' authors' appeals to ideas such as neighbourliness, as well as plantation and civility, should be seen, as they utilised a heavily Protestant presentation of civility: the creation of a godly, peaceful and prosperous society. However, their writings across the 1641-3 period also betray the fact that these communities were still in formation and in flux: the 'Treatise' was as much self-exploration and self-creation on the part of the newcomer community, as it was denigration of the barbarous Irish, who were similarly under construction as a religious and ethnic other in the new circumstances of 1641-2. Of course, the understanding of both civility and of the 'British' efforts to transform Ireland in the 'Treatise' is only one such view. It is nonetheless an important voice in such dialogues. Among other things, examining the 'Treatise' closely is one answer to Armstrong and Ó hAnnracháin's call for greater understanding of community in early modern Ireland. ${ }^{33}$ It also allows us to see the rebellion itself as a competition between communities, but in a different light to earlier historiography: by more carefully interrogating the 'British' and Protestant side of the conflict, and the interactions between colonial and ethnic factors, such as civility and settlement, alongside religious ones.

The careful elucidation in the 'Treatise' of the apparently differing aims of the rebellion highlights this process of ethnic and religious differentiation, and the creation of new communities. The 'Treatise' made clear distinctions between the hostility of the native Irish, and the Old English, summarised in the phrase, 'the Irish are more frequent in expressing hatred to our nation, \& the old English to our Religion'. However, the 1641 rebellion was in many respects a new departure, precisely because of the involvement of the Old English. They presented a curious case for the commissioners, who noted that in previous rebellions it was chiefly the native Irish who were involved, along with 'some few degenerated families of the old English'. However, on this occasion, 'those of English descent being Papists are almost all in this rebellion as deeply interessed as the meere Irish' ${ }^{34}$ Here the idea of degeneration appeared in its traditional form, meaning those of English descent who had adopted Irish customs and practices, and become 'more Irish than the Irish themselves'. ${ }^{35}$ However, in this account, degeneration acquired a new dimension: religion. The Old English community, who previously had not joined with the native Irish against the English state and religion, had degenerated through 'zeale to their religion and hatred to ours', a process which Catholic 'priests, friars and jesuites' were accused of fomenting and accelerating. ${ }^{36}$ Jones utilised older presentations of degeneration, while advancing a new interpretation based on religion. This is significant as it further underlines how religion and religious divisions were emerging as the chief organising poles of conflict in the 1640 s, even as ethnicity continued to play a role.

Catholicism, according to Jones, could be the only tangible reason for the widespread participation of the Old English in the rebellion. He noted that 'the papists especially of English descent lived very plentifully' and in 'comfortable condition':

33 Ibid., p. 13.

34 'Treatise', f. 3v.

35 Kenneth Nicholls, Gaelic and Gaelicised Ireland in the middle ages (Dublin, 1972), pp 12-17; R. R. Davies argued such 'degeneration' was understood as 'literally defecting from and compromising one's own identity as a people': 'The peoples of Britain and Ireland, 1100-1400, I: identities' in Transactions of the Royal Historical Society, 6th series, iv (1994), p. 7.

36 'Treatise', ff $3 \mathrm{v}, 11 \mathrm{v}$. 
material concerns were not to the forefront in pushing them into open revolt. Only religion, or 'pr[e]tense of religion', could induce otherwise 'quiet spirits' to participate in such an action. Further, 'pretended' religious causes increased the violence on display: 'the more erroneous it [religion] is, upon the more violent courses it puts the professors for defense thereof'. ${ }^{37}$ For Jones and his fellow authors, the Old English were overwhelmingly responsible for the religious character of the rebellion. The burning of Bibles, destruction of pews, pulpits and entire churches, and attempted mass conversion were mostly due to the 'hatred' of the Old English for the 'reformed religion'. ${ }^{38}$ However, they argued that Catholic clergy ought to shoulder the great part of the blame for sparking the conflagration. They 'boldly and impudently affrightened them with the danger ... their religion stood in' to incite them into action. This did not completely excuse the Old English, for 'good men and loyall subjects could not possibly but pitch upon other ways \& meanes then treasons, rebellion, murders \& robberies' in order to defend their religion. ${ }^{39}$ Indeed, the very idea of 'defending' Catholicism was an oxymoron to Jones: rather, Catholic tactics were never 'for the defense of one impugned, but for the intended propagating of one freely professed'. 40 The Old English, driven into the arms of 'Irish' rebellion for the first time, were thus driven by 'zeale' for their 'pretended religion'.

The native Irish, contrastingly, were chiefly moved by 'hatred of our nation' rather than religion, at least initially. Their desire 'not to be under the English government or lawes' was one of their chief aims. There was nonetheless inconsistency, as some reportedly desired a putative freedom from 'dependencie upon England', but not from ultimate obedience and loyalty to the English king, while still others plotted 'an intention of renounceing his sacred $\mathrm{Ma}$ [jes]tie' and installing a native Irish king. ${ }^{41}$ Such political and national considerations were still religiously-inflected, with a prophecy of St Patrick for example supposedly foretelling that a king would arise from Ulster, and 'should drive all the mists and darknes out of the kingdome', with the mists and darkness variously interpreted as the English and/or the Protestant religion. ${ }^{42}$ Apparent ancient hatreds and hostilities were called upon. The 'Treatise' authors wrote of the 'mortall hatred against the English' of previous generations, especially in Ulster, and particularly among the O'Neills, frequent enemies of the English crown. Indeed, Shane O'Neill, leader of the sept in the sixteenth century, was reported to have 'strangled some of his people because they eat the bread of the English', while his father, Con, 'cursed his posteritie if they learned the English tongue, or sowed wheat, or built houses after the English fashion'. ${ }^{43}$

Jones and his co-authors thus appeared to have presented binary motives and objectives for the 1641 rebels: the Old English propelled by religion, and the native Irish fuelled by ancient anti-English feeling. However, the 'Treatise' in fact moves beyond these divisions to present a more unified aim to the rebellion than the previous discussion might suggest. First, the native Irish and Old English joined forces

${ }^{37}$ Ibid., f. 9r.

${ }^{38}$ Ibid.

39 Ibid.

${ }^{40}$ Ibid., f. $11 \mathrm{v}$.

${ }^{41}$ Ibid., ff $5 \mathrm{r}-5 \mathrm{v}$; the commissioners only very lightly touch on the rumour of the king's 'commission' for the Irish rebels, describing it as 'pretended', and as part of the 'wild contradictions' of the rebellion (f. 15r).

${ }^{42}$ Ibid., f. 7 r.

${ }^{43}$ Ibid. 
for the first time, a process mostly attributed to the final, total degeneration of the majority of the Old English. This in turn led to the adoption of dual aims for the rebellion, as set out by the 'Treatise' writers at the very beginning. They described the 'twoofold end' of the rebellion as being 'first the extirpation of the English nation; and secondly the abolishment of the Protestant reformed religion'. While still acknowledging that the latter was more associated with 'their religious men and their devouter laicks', the twin aims in fact intersected and became mutually reinforcing. ${ }^{44}$ To eradicate the English was to eradicate Protestantism, and vice versa. The 'Treatise' thus echoes many modern debates about the rebellion, such as those concerning the important leadership of the Old English, and the mingling of religious, colonial and ethnic factors in fuelling violence. ${ }^{45}$ Where it distinguishes itself is in how it synthesised these dimensions, presenting an account that underlined how religion, plantation and older ethnic hostilities were mutually reinforcing and generative, thereby challenging historians to see $1641 \mathrm{in}$ such terms too.

However, perhaps unsurprisingly for a commission composed of clergymen, the religious dimension was still foremost: it provided the structural framework for thinking about 'Britishness' and its associated values in Ireland, especially touching ideas of plantation, civility and improvement. Thus, Jones presented the conflict as one fundamentally driven by religion, since to reject Protestantism was also to reject the wider English or 'British' project in Ireland. The frequency with which settlers were referred to as 'Protestants' as a kind of shorthand, encompassing both English and Scots, underlines this. That Jones and his colleagues saw victimhood, and therefore arguably this 'British' identity, as primarily associated with Protestantism is testified by his description of the rebellion as an act 'done against soe many thousands of protestants onely as protestants', suggesting a principally religious 'hatred and plott'. ${ }^{46}$ This 'British' label did nonetheless carry ethnic connotations, especially associations with the project of plantation and reforming Ireland, as will be explored below.

The 'extirpation' of the Protestant religion was one of the express aims of the rebellion in the eyes of that community. The 1643 'Treatise' described acts of violence that were undeniably religious in character, with Catholic attacks targeting churches, Bibles and even the bodies of Protestants. ${ }^{47}$ These attacks lend serious weight to arguments concerning religion and rebellion, as clear expressions of the 'hatred' of Protestantism. However, the rebellion as a religious conflict was also presented in a less explicit manner by the 1643 'Treatise'. The authors made extensive appeals to neighbourliness, Christian love and friendship, and charity, as further examples of the religious character of the uprising. In doing so, however, their aim was not to show that the Irish acted in putative defence of their religion:

${ }^{44}$ Ibid., f. $2 \mathrm{v}$.

${ }^{45}$ See notes 1 and 18 above.

${ }^{46}$ Ibid., f. 33r.

${ }^{47}$ Ibid., ff 19r-19v; see also Jones, Remonstrance, p. 8; Brian MacCuarta, 'Religious violence against settlers in south Ulster, 1641-2' in Edwards et al. (eds), Age of atrocity, pp 154-75. 
instead, their rejection of such core Christian values underlined that they could not in fact be acting in the name of religion, since no true Christian could endorse such actions. Rather, the rebellion was fundamentally unchristian, and the perceived crusade against the Protestants an unholy war, since it sought to undermine and overthrow core Christian values. These concepts also lay behind much of the characterisation of plantation and wider English attempts to reform Ireland in the 'Treatise', providing further glimpses of the deep entanglement of religion, plantation and claims to civility in seventeenth-century Ireland. The authors were likely acting to reinforce the legitimacy of the supposed efforts to sow such behaviours and beliefs in Ireland, and to speak to an audience both in Ireland and beyond as to their unjustified suffering, their moral claim to the island, and the bonds of fellowship with Protestants in England and elsewhere.

Neighbourliness and neighbourhood were central to early modern English society, and thus it is on some levels unsurprising to see them applied to the Irish context. While something of a nebulous concept - a loose association of ideas such as neighbourhood, quietness, peace and charity — neighbourliness is a useful label to bring all of them together: Jones used the term 'good neighbourhood' in the 'Treatise' itself, often in conjunction with phrases such as 'office of love' ${ }^{48}$ Keith Wrightson described neighbourliness as 'both a centrally important social relationship and a primary social ideal', one that prized harmony and order, the avoidance of conflict where possible, and reconciliation where it had occurred. Neighbourliness combined reciprocity, personal knowledge and charity, all typically bound up in ideas of space and proximity, even if social, economic, demographic and religious developments had seen greater segmentation and stratification of society. ${ }^{49}$ Naomi Tadmor has described it as the 'living idiom' of daily life and social relationships, a central set of governing principles that guided how people (should, at least) interact. ${ }^{50}$

However, neighbourliness was understood fundamentally in religious terms, and as a Christian obligation: it was a spiritual idiom. Wrightson and Tadmor have both shown how neighbour, and especially neighbourliness, were concepts explored mostly in religious literature, especially the catechism and the Bible. The catechetical exposition of the Ten Commandments, especially the fifth to tenth, was often framed as a person's 'neighbourly duties', while Jesus's injunction to 'love thy neighbour as thyself' was considered the social golden rule. Further, the definition of neighbour itself included not only persons known, but also all people unknown, indicating the obligations of charity even to strangers. ${ }^{51}$ To be at loggerheads with a neighbour was not solely 'unneighbourly', but to be 'out of charity': this further stressed the religious significance of community and good relationships, and those 'out of charity' were also advised not to take communion, until they had reconciled. ${ }^{52}$ Those who persisted in disputes, significantly, were often described

48 See, for example, 'Treatise', f. $24 \mathrm{v}$.

49 Keith Wrightson, 'The "decline of neighbourliness" revisited' in Norman L. Jones and Daniel Woolf (eds), Local identities in late medieval and early modern England (London, 2007), pp 19-49, esp. pp 22, 31, 38-9; Ian Archer, In pursuit of stability: social relations in Elizabethan London (Cambridge, 1991), pp 78-9, 92-3; Jonathan Willis, The Reformation of the Decalogue: religious identity and the Ten Commandments in England, c. 1485-1625 (Cambridge, 2017), pp 27, 29, 36109.

50 Naomi Tadmor, The social universe of the English Bible (Cambridge, 2010), p. 13.

51 Wrightson, "The "decline of neighbourliness" revisited', pp 22-4, 32; Tadmor, The social universe, pp 23-49.

${ }^{52}$ Wrightson, 'The "decline of neighbourliness" revisited', p. 30. 
as 'unchristianlike' in their conduct. ${ }^{53}$ Here, there is a similarity with the unchristian Irish. However, there is likely a significant difference between simply being 'unchristianlike' and actually unchristian: while warring neighbours would hopefully reconcile, for the Irish it seemed there might be no such prospect.

It could well be questioned whether such ideas of neighbourliness were applicable in Ireland, given its very different political, social, economic and religious make-up to England, as well of course as the differences in evidence and historiographical development. ${ }^{54}$ Armstrong and Ó hAnnracháin, for instance, have argued that due to the 'intractable' divisions of Irish Christianity, neighbourliness as the guiding social more was less influential than in England, and possessed much less power to restrain conflict. ${ }^{55}$ However, as Joseph Cope has shown, during the rebellion itself some individual Protestant settlers were saved by Irish Catholics, such as Philip MacMulmore O'Reilly's protection of many settlers in Cavan, indicating that despite serious divisions, some cross-confessional neighbourliness was possible. Further, some Irish Catholics even resorted to the language of the good neighbour in defending individual settlers, such as the O'Reillys' defence of George Creighton as a 'kind neighbour' in their protective stance against the earl of Fingall, suggesting both its use in Irish social vocabulary and its position as an apparently powerful rationale for restraint. ${ }^{56}$

Within confessional groups, the desire for community and strong relations was present, but how far this stretched to wider society is uncertain. ${ }^{57}$ Despite some limitations, given its fundamental importance in English society, and the desire to reform Ireland along these lines, neighbourliness was an embedded hope within schemes to civilise: on 14 October 1608, the lord deputy Sir Arthur Chichester wrote to the Privy Council that 'civility and obedience' could be achieved through a well-designed plantation scheme, ${ }^{58}$ later that same month, he wrote that 'peace' would be maintained following the 'well settlement' of Ulster. ${ }^{59}$ Terms such as 'peace' and 'obedience' were key to neighbourliness. In Ireland, they of course could also carry different overtones, particularly of violence: in his 14 October letter for instance, Chichester also acknowledged that 'good quietness' was being maintained through 'cutting off of the swordsmen' who threatened the peace of the kingdom, with the lesson that 'all others will be taught by their fearful example to desist from such violent and disloyal courses'. ${ }^{60}$ It is clear that neighbourliness in an Irish context would likely have had very different meanings for different ethnic and confessional groups.

The ideal of neighbourliness was clearly present to some extent; the reality of religious and ethnic divisions, as well as the threat of violence to maintain it, meant that while 'quietness' may have reigned for the most part, there was likely

${ }^{53}$ Ibid.

${ }^{54}$ For an overview of the development of early-modern English scholarship on 'neighbourliness', see ibid., pp 19-21.

${ }_{55}$ Armstrong \& Ó hAnnracháin, 'Introduction', pp 20, 25.

56 Joseph Cope, 'The experience of survival during the 1641 Irish rebellion' in Hist. Jn., xlvi, no. 2 (June 2003), pp 303-05, 308-11; deposition of George Creighton, 15 Apr. 1643 (T.C.D., MS 832, f. $152 \mathrm{v}$ ).

${ }^{57}$ See, for example, Marie-Louise Coolahan, 'Ideal communities and planter women's writing in seventeenth-century Ireland' in Parergon, xxix, no. 2 (Dec. 2012), pp 69-91.

${ }^{58}$ Lord deputy to Privy Council, 14 Oct. 1608 (Cal. S.P. Ire., 1608-10, pp 68-9).

${ }^{59}$ Lord deputy to [Salisbury], 18 Oct. 1608 (Cal. S.P. Ire., 1608-1610, p. 85).

${ }^{60}$ Lord deputy to Privy Council, 14 Oct. 1608. 
little sense of the creation of a unified, neighbourly community. This is visible in small ways in many quarters, such as Bríd McGrath's exploration of Clonmel, which shows that Protestants were mostly excluded from guilds and serving in key political offices, ${ }^{61}$ Clodagh Tait has likewise shown that both Catholics and Protestants created and maintained ties to their parish church - often regarded as central to community in England ${ }^{62}$ — but that while there were possibilities to cooperate, such as allowing Catholic burials in churches, these sites were also riven with tensions and frequently served to highlight difference rather than reconcile. ${ }^{63}$ It is thus clear that while a kind of everyday toleration may have come into being, ${ }^{64}$ despite the best efforts of 'British' settlers, the kind of neighbourliness envisaged by plantation schemes that would encourage improvement and civilisation had likely not materialised by 1641 in any widespread fashion.

With that in mind, we must then address why themes of neighbourliness figured so strongly in the 1643 'Treatise'. A number of possible reasons emerge: to showcase the peaceful nature of Irish society before the rebellion, and so underline the violence of the rising and the corresponding unchristian nature of the Irish; as an appeal to an audience beyond Ireland, for both aid and recognition of 'British' suffering; as a defence of the wider plantation project and thus a legitimisation of the 'British' presence in Ireland. Cope has argued that the lack of representation of neighbourly relations and friendships is a particular feature of later writings on the rebellion, such as Temple's Irish rebellion; where it appeared, it tended to be solely to underline the perfidy of Irish Catholics in their betrayal of those who blindly and wrongly trusted them. ${ }^{65}$ However, Jones's account is more nuanced, given its stress both on the situation pre-rebellion and the hopes for rebuilding in the future.

The 'Treatise' implied that to some extent, social relations had been good, or at least acceptable, between many newcomer Protestants and Irish Catholics prior to the rebellion. This presentation feeds into wider debates surrounding the extent of interaction between different ethnic and religious groups, as well as the nature and extent of unrest prior to 1641: certainly it was not an event 'out of the blue'. ${ }^{66}$ Reading against the grain somewhat, it is possible to argue that the use of neighbourliness by the deposition commissioners in 1643 implied a certain amount of everyday accommodation, even toleration, prior to October 1641, if its total rejection once the rebellion broke out was as shocking as many proclaimed. That is one line of argument and one that could prove fruitful for future investigation. Indeed, it indicates further the idea of 'competing communities' illustrated earlier, as early modern Irish society before 1641 was clearly a lattice of cross-confessional and multi-ethnic relationships, though still with rival and even hostile visions of the ideal Ireland.

This is turn strengthens the reliance on neighbourliness as a means for highlighting — or exaggerating — the deceit and treachery of their Irish neighbours. The

${ }^{61}$ Bríd McGrath, 'The communities of Clonmel' in Armstrong \& Ó hAnnracháin (eds), Community, pp 106, 117.

${ }_{62}$ Alec Ryrie, Being Protestant in Reformation Britain (Oxford, 2013), esp. pp 317-62.

${ }^{63}$ Clodagh Tait, "“As legacie upon my soule": the wills of the Irish Catholic community, c.1550 - c.1660' in Armstrong \& Ó hAnnracháin (eds), Community, pp 188-91.

${ }^{64}$ Cope, 'Experience of survival', p. 316.

${ }^{65}$ Ibid., pp 313-14.

${ }^{66}$ David Edwards, 'Out of the blue? Provincial unrest in Ireland before 1641' in Ohlmeyer \& Ó Siochrú (eds), Ireland: 1641, pp 95-114. 
Irish feigned good relations and neighbourliness, while harbouring 'hatred' in their hearts. The possible purpose of the 'Treatise' in destabilising the 1643 cessation should, however, give rise to caution in pushing this explanation too far. However, when viewed in light of the self-fashioning and victimhood that were central to the 'Treatise', such an interpretation gains a new dimension. The idealised picture of pre-rebellion Ireland highlighted both the godliness and civility of the Protestant community, and their valiant efforts to extend this to all of Ireland: improving Ireland, to borrow an expression. ${ }^{67}$ The Protestant community was thus consciously presented according to the norms and expectations of good English society. This reinforced its claim to superiority in the Irish context, while legitimising its status as undeserving victims of an overwhelming Irish Catholic cruelty to those beyond Irish shores.

Another consideration is the possibility of an audience beyond Ireland itself. The Remonstrance of 1642 contained a clear appeal for assistance for the suffering Protestants of Ireland. Having described their lamentable condition, the authors asked for 'tender considerations' and 'admittance into your Charity' — further, their pain was on account of 'that your zeal for the Church of God'. ${ }^{68}$ This function of the Remonstrance has been widely noted. ${ }^{69}$ It could be that the reliance on neighbourliness in the later tract was intended as a continuation of this theme, reminding English readers of their duties towards their co-religionists both in Ireland, as well as those who had fled to England and Scotland and relied on charity and the good intentions of family and community while there. ${ }^{70}$ However, the emphasis seems less an appeal to an English sense of pious duty, than a call to arms to defeat 'Gods enemyes', and to 'restore and propagate peace \& truth in this land', as well as in England itself. ${ }^{71}$ While seeking English support, Jones and his colleagues seemed more interested in drawing wider lessons about the dangers of Catholicism - a message that would also have resonated strongly in England, and further afield. The godly were obliged 'to make ours more watchfull and lesse credulous for the future', and to 'take heed' of plots concocted by the 'Romish Clergie': a people so bent on their own power and advantage, that they would 'care not much to set kingdomes yea all Christendome on fire, that they might warme themselves thereby'. ${ }^{72}$ The commissioners' 1643 account is a more advanced consideration of many aspects of the Irish rebellion, one of the most prominent of which was this message to the wider Protestant world. The emphasis on neighbourliness can be read as highlighting the bonds of spiritual brotherhood, beyond even charity or military support.

${ }^{67}$ Barnard, Improving Ireland?, passim; Ohlmeyer, Making Ireland English, p. 100; Thomas Bartlett, Ireland: a history (Cambridge, 2010), p. 90.

${ }^{68}$ Jones, Remonstrance, pp 11-12.

${ }^{69}$ Joseph Cope, England and the 1641 Irish rebellion (Woodbridge, 2009), pp 34-5, 82-3, 94-5; idem, 'Fashioning victims: Dr Henry Jones and the plight of Irish Protestants' in Historical Research, lxxiv, no. 186 (Nov. 2001), pp 370-91; John Cunningham, '1641 and the shaping of Cromwellian Ireland' in Darcy et al. (eds), The 1641 depositions, pp 156-9; Darcy, The 1641 Irish Rebellion, pp 85-93.

${ }^{70}$ Bethany Marsh, 'Lodging the Irish: an examination of parochial charity dispensed in Nottinghamshire to refugees from Ireland, 1641-1651' in Midland History, xlii, no. 2 (2017), pp 194-216; John Young, 'Escaping massacre: refugees in Scotland in the aftermath of the 1641 Ulster Rebellion' in Edwards et al. (eds), Age of atrocity, pp 219-41.

71 'Treatise', ff 36r-36v.

${ }^{72}$ Ibid. 
The weight given to neighbourhood and Christian love in the 'Treatise' likely has several meanings. How this neighbourliness was constructed serves to underline all of them: the delegitimising of Irish conduct, the virtue of the settlers and the potential lessons for fellow Protestants. One key element was the apparent secrecy surrounding the Irish plans and the consequent suddenness of the violence unleashed. The authors described the unwitting and unknowing calm in October 1641:

Yet indeed such was the smooth demeanour of these our evill neighbours, even but the day before that designed for our destruction, that the sharpest sighted, could not discerne even then, one wrinkle in their browes forebodeing such a storme: all the expressions of seeming realitie were still the same in those neerest neighbours, with whom we had many of us long interchanged all friendly offices of love \& good neighbourhood. ${ }^{73}$

There are several elements worthy of consideration here. One is the description of the Irish as 'evill': certainly, the authors were unequivocal in their view of the utter unacceptability of the rebels' conduct. Building on this idea, Jones and his colleagues argued that the rebels had not only deceived their neighbours, but they had then gone on to attack them furiously and without mercy, even those whom they had formerly professed to love and esteem. According to them, many of the victims of Irish aggression were those with whom there had long been 'friendly offices of love \& good neighbourhood' ${ }^{74}$ In her study of the biblical origins of concepts of neighbourliness in early modern England, Tadmor argued that neighbourliness and its biblical imperative became the chief 'measure against which acts of transgression were to be judged'. ${ }^{75}$ In the Irish context, this stress on the 'good neighbourhood' that had seemingly prevailed before the rebellion broke out served to further highlight the 'cruelty' of the Irish during the rising. ${ }^{76}$ In some places, this feigned friendship was used to trick acquaintances and neighbours, such as persuading them into giving up their arms and ammunition, or promising to safekeep goods (and often persons too) - commitments that were near-universally broken. ${ }^{77}$ These stories, but especially the implicit image of an orderly society before the rising, emphasised the unwarranted violence against the Protestant community. It also underlined their important role in upholding moral and civic standards in prerebellion Ireland: a seeming beacon of godliness and civility in a country otherwise mired in superstition and barbarism.

Further Irish manipulation was apparently at work among the Scottish planters. The 'Treatise' argued that Irish overtures towards the Scots, and the lack of violence towards them in the early stages of the rebellion, were cynical plays on expectations of neighbourly conduct. The Irish, they said, professed to love the Scots as their brethren, with their quarrel being with the English alone. Such conduct utilised expected behaviour, married with apparent ethnic harmony in the face of the hated English, to show yet again how deceitful and sly the rebels were in the pursuit of their wicked aims. To their credit, according to the authors, few Scots were 'intrapped' by these overtures, but they did note that the initial hesitation caused

${ }^{73}$ Ibid., f. $24 \mathrm{v}$.

${ }^{74}$ Ibid., f. $30 \mathrm{v}$.

75 Tadmor, The social universe, p. 42.

${ }^{76}$ It is interesting that the word 'hatred' occurs thirty-three times in the 'Treatise', indicating the stress placed on this feeling by the authors.

77 'Treatise', f. 30v. 
by the Irish approach to the Scots community inhibited effective joint action with their English co-religionists in those early stages of the rising. ${ }^{78}$ The position of the Scots in the rebellion has long attracted particular discussion among historians, but it is clear that for Jones at least, they were always intended as targets. It was merely a case of when. ${ }^{79}$ By including the Scots so explicitly, it is possible to see the attempts to create coherence among the victims, a smoothing out of the differences between the various settler communities. Just as the Irish were marshalled into the category of Catholic, unchristian-like rebels, so Protestant self-fashioning was also at work, presenting shared interests, enmities, and indeed identities: Protestantism itself provided a useful umbrella under which to gather most English and Scots, and forge a unified front, even in the face of tensions both before the rebellion began, and in the immediate context of $1643 .{ }^{80}$ The controversy surrounding the cessation cannot be discounted as a driving force here, with Jones and his colleagues seeking to underline decisively what brought the 'British' of Ireland together: their shared Protestantism, which should form the basis for a concerted attack against the evident evils of Catholicism. ${ }^{81}$ The 'Treatise' allows us glimpses into that effort, and the simultaneous construction of ideas of Protestant, Catholic, English/ British and Irish.

This abandonment of all pretences of neighbourliness, Christianity and indeed any semblance of so-called civilised conduct led the authors of the 'Treatise' to describe the Irish as the worst of any people in terms of their 'cruelty' and 'barbarism'. Their dissimulation and concealing of their 'true' nature placed them beyond comparison. Nevertheless, the authors did make efforts to historicise and evaluate the rebellion in relation to other instances of violence, such as the St Bartholomew's Day massacre of 1572 in France, which, though bloody, was still 'vastly inferiour' to the Irish case. ${ }^{82}$ Similar conclusions were reached about events including the Sicilian Vespers (1282), and the persecution of the Waldensians (beginning c.1184) and the Albigensians (1209-29), with the Waldensian and Albigensian atrocities noted as occurring during a legitimate war waged against them, versus the 'sodaine and unprovoked' Irish violence. ${ }^{83}$ The impetus to historicise and contrast events, and especially to claim that an incident surpassed all comparison, was also a feature of eyewitness accounts of atrocity during the Thirty Years War. Hans Medick has argued that such tendencies arose from the desire to 'demonstrate

${ }^{78}$ Ibid., f. $23 \mathrm{v}$.

79 Canny, Making Ireland British, pp 478-83, 492-3; Aoife Duignan, 'The Scottish response to the 1641 rebellion in Connacht: the case of Sir Frederick Hamilton' in David Edwards, with Simon Egan (eds), The Scots in early Stuart Ireland: union and separation in two kingdoms (Manchester, 2016), pp 230-50.

${ }^{80}$ For discussion of tensions with Scots on plantations, see Canny, Making Ireland British, pp 192-200; Armstrong, Protestant war, p. 10; David Stevenson, Scottish Covenanters and Irish Confederates: Scottish-Irish relations in the mid-seventeenth century (Belfast, 1981), p. 14; for the religious diversity of settlers, see David Edwards, 'A haven of popery: English Catholic migration to Ireland in the age of plantations' in Alan Ford and John McCafferty (eds), The origins of sectarianism in early modern Ireland (Cambridge, 2005), pp 95-126.

${ }^{81}$ For discussion of tensions surrounding the 1643 cessation, see Micheál Ó Siochrú, Confederate Ireland: a political and constitutional analysis (Dublin, 1999), pp 64, 68-9; Redmond, '(Re)making Ireland British', pp 57-78.

82 'Treatise', f. 28 r.

${ }^{83}$ Ibid. 
composure' in the face of tragedy, but enabled 'moral, theological and political judgment' on the part of the suffering. ${ }^{84}$ The condemnation of Irish Catholics as unchristian in the 1643 narrative certainly bears such traits, with a comprehensive defeat the only possible remedy for the chaos unleashed.

The 'Treatise' authors offered a carefully-constructed narrative of Irish behaviour during the rebellion, drawing on a range of religious language, ideas and expectations. Irish Catholics could be cast not only as 'unchristianlike' and uncharitable in their conduct towards their Protestant neighbours, but as actually unchristian in their total eschewal of the expected norms of neighbourliness and fraternal love. ${ }^{85}$ The emphasis on neighbourliness in their tract was intended to demonise, to warn (with an eye to fellow Protestants both in Ireland and Britain) and to uphold 'British' Protestants' moral standing even in the face of disaster. The 'wicked' Irish conduct meant they could not claim to be defending their religion - they had repeatedly violated the most basic and fundamental rule for Christians. The attack on Protestantism was an attack against this very way of living together, which lay at the heart of the properly ordered early modern community. The 1643 'Treatise' went a step further in this articulation of an 'unholy' war, by bringing in the concept of civility. To murder one's neighbour was to reject a fundamental Christian commandment; to reject the very idea of neighbourliness and good order was to step even further down the road of barbarism. For the 'Treatise' authors, neighbourliness, good order and civil living were intimately and inextricably tied up with the project of plantation, and with the introduction not only of Protestantism, but also ideas of improvement and civility. The attack on Protestantism was perceived as an attack against this very way of living together, which lay at the heart of the properly ordered early modern community.

That plantation, civility, improvement and Protestantism were entangled not only in early modern Ireland but more widely is well recognised. ${ }^{86}$ While Ireland has been seen as playing a role in the development of Protestantism-infused missions of colonisation, conquest and conversion, it has at times been neglected in considering the evolution of ideas such as improvement and its religious foundations. ${ }^{87}$ Toby Barnard's argument that 'improvement functioned like a creed' can be

${ }^{84}$ Hans Medick and Patricia Selwyn (trans.), 'Historical event and contemporary experience: the capture and destruction of Magdeburg in 1631' in History Workshop Journal, no. 52 (2001), p. 30.

${ }^{85}$ Hall \& Malcolm, 'Understanding sexual violence', p. 58.

${ }^{86}$ D. Alan Orr, 'Protestant military humanism in early Stuart Ireland' Hist. Jn., lxii, no. 1 (Mar. 2019), pp 79, 85-7; Barnard, Improving Ireland?, pp 13, 28; Thomas, In pursuit of civility, pp 97-8, 229; Bartlett, Ireland, p. 90; Canny, Making Ireland British, pp 38, 2989; Carla Gardina Pestana, Protestant empire: religion and the making of the British Atlantic world (Philadelphia, PA, 2009), pp 92-5, 106; Adrian Chastain Weimer, Martyrs' mirror: persecution and holiness in early New England (Oxford, 2011), pp 121-4, 130; Joan Redmond, 'Memories of violence and New English identities in early modern Ireland' in Historical Research, lxxxix, no. 246 (Nov. 2016), pp 716-21, 724-5, 729; Ohlmeyer, Making Ireland English, pp 9-10.

${ }^{87}$ See, for example, Slack, who argues that North American discourses of improvement were more dominant and influential than in Ireland: The invention of improvement, pp 262-3. 
taken to show its ideological dominance in the seventeenth century (especially its latter half), but also to indicate improvement's reliance on the morals, rhetoric and imagery of religion as both founding principle and to its ongoing development as a key early modern idea. ${ }^{88}$ Nowhere was this more in evidence in Ireland, where Protestantism was at the heart of plantation projects, and the drive to reform and improve. The 1641 rebellion proved a physical challenge and setback to these schemes, and prompted reflection on the origins and development of the plantations, and what had been achieved. The 1643 'Treatise' served as a chronicle of the uprising, but it also offered a window into wider issues of what Ireland was in 1641 , and where it should be.

Plantation schemes supported true religion through their promotion of civility, improvement and general 'good neighbourhood', while civility, once established, promoted true religion. The forty years preceding the rebellion, when plantations had proceeded apace, were presented as a kind of 'golden age' for Ireland, with 'examples of civilitie everywhere scattered among them', resulting in a 'flourishing country' that 'subdued their former rudenes'. Plantation was here idealised, producing the 'happy fruits' of 'civilitie' that in time banished rudeness and barbarism. ${ }^{89}$ However, the Irish had proved 'monstrous and ungratefull' in their destruction of such endeavours, with a 'secret malice' festering even as they professed to enjoy the prosperity brought by 'British' efforts. Probing the root of this malice, Jones and his co-authors attributed it to a 'most imbittered hatred and spitefull rancour against our very names and nation'. 90

However, this anti-English sentiment, and with it the 'hatred' for the supposed civility and improvement of the plantations, fused with anti-Protestant sentiment. Old English and native Irish had joined in rebellion, and their previously-disparate aims, to eliminate Protestantism and to eradicate Englishness, had become entangled into one uprising aimed at the totality of the Protestant and English (or 'British') presence in Ireland. The discussion in the 'Treatise' of the attack on plantation was immediately followed by the examination of the destruction of Protestant Bibles and churches, showing a link between these endeavours towards civility, and the conversion of the population. However, the Irish had also rebelled 'against the light', and through their 'spight and cun[n]ing (as may seeme) shew them resolved, that our religion and civilitie' should be destroyed completely, and prevented from ever putting down new roots. ${ }^{91}$ The rebellion was not solely a religious conflict, nor one fuelled exclusively by ethnic animosities: those hostilities had come together, with violence targeted at the godly civility of the newcomers.

The illegitimacy of such aims was never in doubt. For Jones, the uprising was almost incomprehensible on account of the progress that had been made in improving Ireland. 'We should more wonder, from whence this high disgust or rather a kind of antipathy should proceed', he wrote, for even Irish Catholics themselves 'cannot but confesse they have abundantly gained by us in all manner of improvements', ranging from cultivation and livestock, to 'fame \& respect $\mathrm{w}[\mathrm{i}]$ th other countreyes'. ${ }^{2}$ Where then did this seemingly pure hatred emanate from? One

88 Barnard, Improving Ireland, 13; Quentin Skinner, 'Moral principles and social change' and 'The idea of a cultural lexicon' in Visions of politics (3 vols, Cambridge, 2002), i, 147$54,173-4$

89 'Treatise', f. $18 \mathrm{r}$.

90 Ibid.

91 Ibid., f. 19r.

92 Ibid., f. $21 \mathrm{v}$. 
answer lay in religion, or rather its perversion: Catholics were 'seduced' by the devil, but believed that Protestants were devils themselves, and thus bore an ingrained 'hatred to our soules' that prompted violence. Another lay in the perception of their Protestant neighbours as 'incroachers upon them', people they claimed were the 'scum[m]e of England' come into Ireland and who displaced natives. Religious and ethnic hatreds were brought together: 'they thought themselves the onely men for reestablishment of their religion', while casting 'intollerable ... reproaches' upon the 'English nation'. ${ }^{93}$

It must be borne in mind that in doughtily defending the plantations and their achievements, Jones and his colleagues were likely also attempting to deflect the criticism of the schemes and their failings that circulated both before and after 1641. Plantations, from the Munster endeavour in the late sixteenth century through to the Ulster undertaking and other seventeenth-century designs, had been constantly scrutinised and found wanting. In the aftermath of the collapse of the nascent Munster plantation in 1598, there were recriminations and reproaches for the apparent abject deficiency of the scheme and of the settlers. ${ }^{94}$ Later complaints ranged from the persistence of Irish tenants on lands theoretically closed off to them, to failures to construct adequate accommodations, fortifications and churches, and the generally dissolute living of the settlers - the accusation that they constituted the poor and 'scume' of England was certainly not solely an Irish one. ${ }^{95}$ It is unlikely that Jones and his colleagues were unaware of such criticisms when writing their tract. However, their aim was likely akin to their smoothing of differences within the 'British' community - while the plantations did have faults, the commissioners were evidently determined to present them as largely successes, that had been thrown down by the 'wickednes' of those who rejected true religion and the 'manyfold benefits \& great improovements' of 'civility'. 96

One of the most important ways that Jones tried to smooth difference within his community of victims was in the use of 'British' as a key term. Nowhere does he define this term, though it is clear that he identifies it with Protestantism, since frequently 'Brittish' and 'protestant' are to be found joined. ${ }^{97}$ The use of both 'English' and 'British' in this article reflects the mixed terms in the 'Treatise', which continued to use English and Scottish as labels: at times, 'English laws' were specified for example. ${ }^{98}$ At other times, 'English' and 'Scottish' were used together in descriptions of the plantation settlers, rather than 'British'.99 However, that 'British' is probably meant as an inclusive description of all settlers in Ireland, and certainly the Protestant ones, is evident through its use in contexts such as in the account of the 'common aimes of the Brittish here planted', since it is carefully noted elsewhere that both English and Scots were included in the seventeenth-century schemes. ${ }^{100}$ Elsewhere, the hostility of the Irish towards

93 Ibid., ff 21v-22r.

94 Canny, Making Ireland British, pp 209-10, 213-14, 240-58; Redmond, 'Memories of violence', pp 711-21.

95 Canny, Making Ireland British, pp 253-4; Eamon Darcy, 'The social order of the 1641 rebellion' in Darcy et al. (eds), The 1641 depositions, p. 98.

96 'Treatise', f. 10v.

97 See, for example, ibid., ff 2v, 10v, 13v, 23v, 27r, 29r.

98 Ibid., f. 5 r.

99 See, for example, ibid., ff $2 \mathrm{v}-4 \mathrm{v}$, with repeated usage.

100 Ibid., f. 35 r. 
'English and Scottish men ... alive in the kingdome' also indicates a certain solidarity between the two groups. ${ }^{101}$ The 'Treatise' dismissed categorically any suggestion that the Scots were somehow in league with or protected by the Irish, despite claims about the lack of violence directed against them initially. That the Irish later 'fell on them' with such rage and ferocity indicates little doubt as to the true regard the Scots were held in, and their identification as being among the Protestant, alien 'incroachers'. ${ }^{102}$

The use of 'British' has been noted before by historians, especially when pointing out the use of the term by those giving depositions and documenting their experiences. ${ }^{103}$ Others, such as Nicholas Canny, Robert Armstrong and Jane Ohlmeyer, have also grappled with it. In Canny's case, despite the central thesis of 'making Ireland British', there is little sustained exploration of what it meant beyond the mere involvement of both English and Scottish actors in plantation schemes; further, he argues that the deposition commissioners typically reserved the term 'British' for those 'of English birth', as a marker of status. ${ }^{104} \mathrm{He}$ does not fully interrogate the components of 'Britishness', beyond the joint participation of the English and Scottish settlers in a 'civilizing and reforming endeavour', and especially the religious solidarity emphasised by Jones. ${ }^{105}$ Robert Armstrong also emphasises 'British' as a joining of English and Scottish together, even if tensions between the two meant it was not a straightforward term. He also states that 'British' was revitalised as a term owing to the exigencies of 1641 - a claim which would seem to have merit in light of this 'Treatise'. ${ }^{106}$ Focusing on Randal MacDonnell, marquis of Antrim, Ohlmeyer argues that many men of his standing were often deeply immersed in 'British' politics, with Antrim an important case study of a seemingly peripheral figure who was actually heavily involved with English, Scottish and Irish affairs; however, she does not interrogate this 'Britishness' beyond the 'sphere of British politics', conceived of as the 'equilateral triangle' of British and Irish military manoeuvres, conspiracies and machinations at the highest levels of political life. ${ }^{107}$ It is clear that 'British' needs some re-evaluation, both as a term more generally used to describe the transformations underway in seventeenth-century Ireland, and one revived by conflict and violence.

Ohlmeyer indeed largely dismisses the idea of 'Britishness' in favour of 'English': the systems of government, law and tenure among others were English, along with the English language, English customs, and the English religion, in the form of the Church of Ireland. Further, she argues that the Catholic aristocracy, even those of 'British' origin such as the marquis of Antrim, were able to 'co-opt the colonial process to strengthen their regional power bases', and even 'to subvert the original civilizing

101 Ibid., f. 3r.

102 Ibid., ff 15r, 25r; the use of 'incroachers' can be found at f. 22 r.

103 Eamon Darcy, 'Ethnic identities and the outbreak of the 1641 rebellion in Antrim' in Journal of Irish and Scottish Studies, vi, no. 2 (spring 2013), pp 31-52.

104 Canny, Making Ireland British, pp 197, 236; the claim about the deposition commissioners is at p. 483.

105 Nicholas Canny, 'The origins of empire: an introduction' in idem (ed.), The Oxford history of the British Empire, i: the origins of empire (Oxford, 1998), pp 2, 10-12.

106 Armstrong, Protestant war, pp 10, 97-8.

107 Jane Ohlmeyer, Civil war and Restoration in the three Stuart kingdoms: the career of Randal MacDonnell, marquis of Antrim, 1609-1683 (2nd ed., Dublin, 2001), pp 10-14, 287-9. 
agenda'. ${ }^{108}$ Certainly the models adopted were mostly English, rather than Scottish (even lowland Scottish). However, the 1643 'Treatise' complicates this picture somewhat by underlining the linkage of Protestantism with the civilising mission: what was being aimed at was a godly civility, meaning Protestant. This does not mean that Catholics were excluded from partaking of improvement — in addition to Ohlmeyer, Barnard has shown that this was the case for the later seventeenth century $^{109}$ — but that claims to 'Britishness' represented a kind of mainstream religious and colonising position: the 'Treatise' authors likely intended it as a shorthand for these crucial, overlapping characteristics.

While its use here points towards efforts to create a unified interest among the Protestant newcomers, it must be recognised that it was both a flexible category, and one that cannot be seen as universal. It was a convenient smoother of difference. Barnard has identified this smoothing effort elsewhere, with emphasis on the commitment to improving Ireland among the dispossessed settlers in England during the later 1640s and 1650s. These years, he argued, were critical in establishing the settlers' right to return and resume their work, and to later go on to form an important part of the Anglo-Irish elite of the later seventeenth and eighteenth centuries. ${ }^{110}$ The fierce commitment to Protestantism, and that Protestantism as the guiding moral light behind the equally determined dedication to 'civility' and improvement, were the chief characteristics of 'Britishness' as defined by the 'Treatise' authors. Given their important role in not only collecting testimonies, but in acting as interpreters of the rebellion, their construction of a 'British' identity must be considered an important moment in this emerging Anglo-Irish community that would dominate for several centuries.

In addition to its treatment of 'Britishness', the 'Treatise' also deserves a place among the canon of writings on Reformation and plantation in Ireland for its careful advancement of a sophisticated vision of 'Protestant civility', and as part of a series of such writings exploring improvement in the mid century years. It locates Ireland firmly in the midst of discussions surrounding both religion and progress, and its integration of these concerns gives it an extra dimension in the debates surrounding colonisation, especially in the New World. Paul Slack has argued that ideas of improvement were more dominant in English North America and the Caribbean than in Ireland, while Adrian Chastain Weimer has shown the links between religious imagery, especially martyrdom, and colonisation in New England. ${ }^{111}$ However, this account underlines the strong commitment of the 'British' of Ireland not only to improvement, but to a specifically Protestant vision of improvement that privileged 'civility' as inextricably entwined with the true faith, with mutual benefits and outcomes.

Closer scrutiny of this under-utilised 'Treatise' proves very revealing. Written by a team of authors led by Henry Jones, the account offers crucial insights into the origins and conduct of the rebellion at a relatively early stage in its evolution. Those same authors were arguably among those with the most intimate

108 Ohlmeyer, Making Ireland English, pp 10-11.

109 Barnard, Improving Ireland?, pp 1-40.

110 Ibid., p. 28.

111 Slack, The invention of improvement, pp 262-3; Weimer, Martyrs' mirror, pp 121-4. 
understanding of the uprising, through their work collecting the depositions, and the narrative owes much to those same depositions. Further work on this use of the depositions as a legitimising, authoritative pillar in describing the truth of the rebellion will undoubtedly prove illuminating, for deeper understandings of 1641 and its circumstances, and wider trends in early modern history-writing and record-keeping.

The account offers up numerous arguments concerning and vignettes into the rebellion, and wider Irish society. The seemingly bifurcated aims of the two groups of rebels, the Old English and native Irish, were explored: the Old English acted out of 'zeale' for their religion, while the native Irish were moved by 'hatred' of the 'English nation'. However, through showing both how these two groups came together as one actor in rebellion, as well as the blending of their aims, the 'Treatise' propounds a unified aim for the uprising: it was an 'unholy' war aimed at eradicating Protestant civility from Ireland. Religion and colonisation were inescapably entangled in both the rebels' minds and the minds of their victims: the rebellion constituted a total war against the Protestantism and civility of the settlers. Their religion informed their approach to settlement and improvement, especially through moral standards of neighbourliness and Christian love; the plantations, likewise, reflected deeply Protestant-hued ideas of moral living and godliness. The 'British' of Ireland, as described by Jones and his colleagues, promoted the true faith and the benefits of plantation as entwined and inseparable.

The consequences of this for understandings of communities and identities in early modern Ireland, even before the rebellion, are significant. There has been much debate surrounding the increasing connections between the native Irish and the Old English, brought together under the banner of 'Irish' through their shared Catholicism. ${ }^{112}$ A similar effort can be tentatively identified on the other side: the 'Treatise' demonstrates an important attempt not only at creating a coherent community of victims, but also attempts to smooth over differences within the Protestant community in the face of such an onslaught, and to tie them together as defenders of the true faith and of civility. The widespread use of 'British' in the 'Treatise' must be seen as a crucial part of this effort to give greater unity and shared values to this community. The rebellion itself can be cast in terms of 'competing communities', or visions of community, which always entailed a certain degree of homogenisation. These insights concerning the 'British' of Ireland only serve to strengthen the case of linking Ireland with the emerging Atlantic world, not merely as a 'laboratory for empire'113 but as one of its chief creators, inventing and reinventing the core ideas, visions and idioms that crafted and governed it.

112 Bernadette Cunningham, The world of Geoffrey Keating: history, myth and religion in seventeenth-century Ireland (Dublin, 2000), pp 105-21.

113 Jane Ohlmeyer, 'A laboratory for empire?: Early modern Ireland and English imperialism' in Kevin Kenny (ed.), Ireland and the British Empire (Oxford, 2005), pp 26-60; eadem, 'Eastward enterprises: colonial Ireland, colonial India', Past \& Present, no. 240 (2018), pp 83-118; Linda Colley, Britons: forging the nation, 1707-1837 (London, 1992), esp. chapter 1, 'Protestants'. The author wishes to thank John Morrill, Laura Gowing, Simone Maghenzani, Hannah Murphy, Sarah Ward, Tim Wales and Keith Pluymers for their advice with this article. 